\title{
Pemberian jahe instan terhadap kejadian mual muntah dan asupan energi pada ibu hamil trimester pertama
}

Effect of instant ginger on occurrence of nausea vomiting pregnancy and energy intake in first trimester pregnant women

\author{
Nurfalah Setyawati ${ }^{1}$, Mae Sri Hartati Wahyuningsih ${ }^{2}$, Detty Siti Nurdiati ${ }^{3}$
}

\begin{abstract}
Background: Pregnancy causes increased energy metabolism, therefore needs of energy and other nutrients increase during pregnancy. Lack of energy and nutrients could adversely affect the mother and fetus. Nausea and vomiting is a common problem in the first trimester of pregnancy. If not treated the mother and fetus can be at risk of malnutrition due to lack of energy intake. Traditional treatment is an option that is considered safe. Ginger has been used to treat a variety of medical problems including nausea and vomiting. Ginger works in the digestive tract by increasing the gastric and intestinal motility. Objective: This study aimed to determine the effectiveness of instant ginger containing $290 \mathrm{mg}$ ginger juice, to reduced the incidence of nausea and vomiting of pregnancy and increased maternal energy intake during the 24 hours. Method: The study design is experimental, pre-post control group, involving 101 pregnant women with gestational age less than 15 weeks in RSB Sayang Ibu, puskesmas Klandasan Ilir and Sepinggan in Balikpapan. Research subjects were drawn at random and given the instant ginger or placebo, 2 times a day for a week. All of the subjects were assessed on the level of nausea, vomiting and a 24-hour energy intake during pre and post intervention. The use of drugs or supplementation from the doctor/midwife were recorded and not be stopped. Results: The rate of nausea and vomiting decreased significantly in the ginger group (52\%) compared to placebo (17.7\%) ( $<<0.05)$. Instant ginger may reduce nausea and vomiting rate 6 times higher than placebo $(p<0.05)$. The average amount of energy intake (calories) for 24 hours increased significantly in the ginger group (1629.58 kcal $\pm 468.04 \mathrm{kcal}$; $p<0.05)$ compared to placebo $(1160.27 \mathrm{kcal} \pm 341.85 \mathrm{kcal} ; \mathrm{p}>0.05)$. Instant ginger may increase the average amount of energy intake 24.5 times higher than placebo ( $p<0.05)$. Conclusion: Instant ginger effective to reduce nausea and vomiting of pregnancy and increase the amount of energy intake (calories) in pregnant women who experience nausea and vomiting of pregnancy.
\end{abstract}

KEY WORDS: ginger, nausea and vomiting of pregnancy, energy intake

\begin{abstract}
ABSTRAK
Latar belakang: Kehamilan menyebabkan meningkatnya metabolisme energi sehingga kebutuhan energi dan zat gizi lainnya meningkat selama kehamilan. Kekurangan energi dan zat gizi dapat berdampak buruk pada ibu maupun janin. Mual dan muntah merupakan keluhan yang sering terjadi pada kehamilan trimester pertama. Bila tidak diatasi, ibu dan janin dapat berisiko kekurangan gizi karena kurangnya asupan energi. Pengobatan herbal secara tradisional merupakan pilihan yang dianggap aman. Jahe telah banyak digunakan untuk mengatasi berbagai keluhan medis diantaranya mual dan muntah. Jahe bekerja pada saluran pencernaan dengan meningkatkan motilitas gaster dan usus halus. Tujuan: Mengetahui efektivitas jahe instan yang berisi sari jahe 290 mg terhadap penurunan kejadian mual muntah dan peningkatan jumlah asupan energi 24 jam pada ibu hamil trimester pertama. Metode: Desain penelitian eksperimen, pre-post control group, melibatkan 101 wanita hamil dengan usia kehamilan kurang dari 15 minggu di RSB Sayang Ibu, Puskesmas Klandasan Ilir, dan Puskesmas Sepinggan di wilayah Balikpapan. Subjek penelitian diambil secara acak dan diberikan jahe instan atau plasebo, 2 kali sehari selama seminggu. Seluruh subjek penelitian dinilai tingkat mual muntah dan asupan energi 24 jam selama pre dan pos intervensi. Penggunaan obat atau suplementasi dari dokter/bidan dicatat dan tidak dihentikan. Hasil: Tingkat mual muntah mengalami penurunan secara signifikan pada kelompok jahe $52 \%$ dibanding plasebo $17,7 \%(\mathrm{p}<0,05)$. Jahe instan dapat menurunkan tingkat mual muntah 6 kali lebih besar dibanding plasebo ( $<<0,05)$. Jumlah rerata asupan energi 24 jam meningkat secara signifikan pada kelompok jahe $(1629,58 \mathrm{kcal} \pm 468,04 \mathrm{kcal} ; \mathrm{p}<0,05)$ dibanding plasebo $(1160,27 \mathrm{kcal} \pm 341,85 \mathrm{kcal} ; \mathrm{p}>0,05)$. Jahe instan dapat meningkatkan rerata jumlah asupan energi 24,5 kali lebih besar dibanding plasebo $(\mathrm{p}<0,05)$. Simpulan: Jahe instan efektif untuk menurunkan mual muntah kehamilan dan meningkatkan jumlah asupan energi (kalori) pada ibu hamil yang mengalami mual muntah kehamilan.
\end{abstract}

KATA KUNCI: jahe, mual muntah kehamilan, asupan energi

${ }^{1}$ Korespondensi: Jl. Indrakila No.107 RT 04, Kel. Gunung Samarinda Baru, Balikpapan, Kalimantan Timur, 76125, e-mail: nurfalahsetyawati@yahoo.com
${ }^{2}$ Departemen Farmakologi dan Terapi Fakultas Kedokteran Universitas Gadjah Mada, Jl. Farmako, Sekip Utara, Yogyakarta 55281 ${ }^{2}$ Departemen Farmakologi dan Terapi Fakultas Kedokteran Universitas Gadjah Mada, Jl. Farmako, Sekip Utara, Yogyakarta 55281 


\section{PENDAHULUAN}

Kehamilan menyebabkan meningkatnya metabolisme energi, oleh karena itu kebutuhan energi dan zat gizi lainnya meningkat selama kehamilan (1). Kekurangan energi dan zat gizi dapat berdampak buruk pada ibu maupun janin. Penyebab kurang gizi pada ibu hamil trimester pertama yang paling sering terjadi adalah mual muntah kehamilan (emesis gravidarum), penyakit infeksi, dan status gizi kurang pada prakonsepsi (2). Emesis gravidarum atau mual dan muntah merupakan keluhan yang sering terjadi pada wanita hamil terutama di trimester pertama. Mual muntah kehamilan dapat terjadi setiap saat sepanjang hari (kecuali saat tidur) dan bukan merupakan penyakit (3).

Herbal sebagai unsur natural dapat digunakan untuk mengatasi mual dan muntah pada awal kehamilan. Jahe (Zingiber officinale $\mathrm{R}$ ) telah banyak digunakan untuk mengatasi berbagai variasi keluhan medis berupa mual dan muntah (4). Efek antiemetik pada jahe dikaitkan dengan aktivitas kombinasi zingerones dan shogaols yang terkandung dalam jahe (5). Penelitian tentang efektivitas ekstrak jahe dengan menggunakan metode randomized controlled trial (RCT) menyimpulkan bahwa ekstrak jahe dapat digunakan untuk mengatasi mual dan muntah pada kehamilan (6-12). Review dan evaluasi dengan studi evidence base juga menyimpulkan bahwa jahe dapat digunakan untuk mengatasi mual dan muntah pada kehamilan $(13,14)$.

Deteksi ibu dengan kehamilan berisiko tinggi merupakan program pelayanan kesehatan ibu dan anak yang sedang ditingkatkan di Dinas Kesehatan Kota Balikpapan untuk mencapai target Millennium Development Goals (MDGs). Pada tahun 2011, didapatkan 2.888 wanita terdeteksi berisiko tinggi kehamilan yang dapat menyebabkan komplikasi kehamilan sampai dengan kematian ibu dan anak (15). Tujuan penelitian ini adalah untuk mengetahui efektivitas jahe instan dan mengidentifikasi faktor-faktor yang berpengaruh dalam menurunkan kejadian mual muntah serta mengetahui peningkatan asupan energi pada ibu hamil trimester pertama.

\section{BAHAN DAN METODE}

Penelitian ini merupakan penelitian true experiment dengan desain pre-post control group. Pemberian jahe instan maupun plasebo kepada sampel berdasarkan pengacakan melalui nomor urut pemeriksaan, nomor pemeriksaan ganjil diberikan jahe instan dan nomor pemeriksaan genap diberikan plasebo. Waktu penelitian dimulai pada 23 Maret - 10 Juli 2013 di Rumah Sakit Bersalin (RSB) Sayang Ibu, Puskesmas Klandasan Ilir, dan Puskesmas Sepinggan, Balikpapan.

Populasi penelitian adalah semua ibu hamil dengan umur kehamilan kurang dari 15 minggu di wilayah Balikpapan. Besar sampel ditetapkan berdasarkan rumus perbedaan dua mean (16), dengan tingkat kepercayaan (CI) $95 \%$; power ( $\beta$ ) $80 \%$; standar deviasi sebesar 1,2; dan mean difference yaitu 0,77 (8); perkiraan sampel drop out sebesar $20 \%$ sehingga jumlah sampel masingmasing kelompok adalah 47 ibu hamil. Teknik sampling yang digunakan adalah cluster random sampling dan consecutive sampling. Subjek penelitian yang memenuhi kriteria inklusi yaitu ibu hamil dengan keluhan mual atau mual muntah, usia kehamilan kurang dari 15 minggu yang dipastikan dengan hari pertama haid terakhir (HPHT) dan ultrasonografi (USG), serta bersedia menjadi sampel dengan mengisi informed consent. Subjek akan dikeluarkan dari penelitian jika keluhan mual dan muntah bukan karena kehamilan (disfungsi gastrointestinal seperti gastritis dan batu empedu), alergi terhadap jahe, dan mengalami hiperemesis gravidarum dengan komplikasi (disertai dehidrasi berat). Desain penelitian ini secara jelas ditampilkan dalam Gambar 1.

Variabel independen adalah pemberian jahe atau plasebo pada wanita hamil dengan emesis. Variabel dependen adalah tingkat mual muntah dan jumlah asupan energi sedangkan variabel luar adalah usia kehamilan, paritas, dan penggunaan suplementasi (vitamin $\mathrm{B}_{6}$, asam folat, zat besi, dan mikronutrien lain). Pengukuran berat dan tinggi badan digunakan untuk melihat homogenitas subjek penelitian. Subjek penelitian dinilai tingkat mual muntah dan jumlah asupan energi selama 3 hari berturut-turut sebelum diberikan jahe instan atau plasebo (pre-intervensi). Selanjutnya, selama pemberian jahe instan atau plasebo selama 1 minggu, subjek penelitian akan dinilai tingkat mual muntah sebanyak 7 kali (1 kali/hari) dan penilaian jumlah asupan energi sebanyak 3 kali (2 hari kerja dan 1 hari libur). Subjek penelitian diberikan jahe instan $10 \mathrm{~g}$ (berisi sari jahe $290 \mathrm{mg}$ ) atau plasebo $10 \mathrm{~g}$ (gula) sebanyak 2 kali sehari selama 1 minggu. Subjek penelitian tersamar 


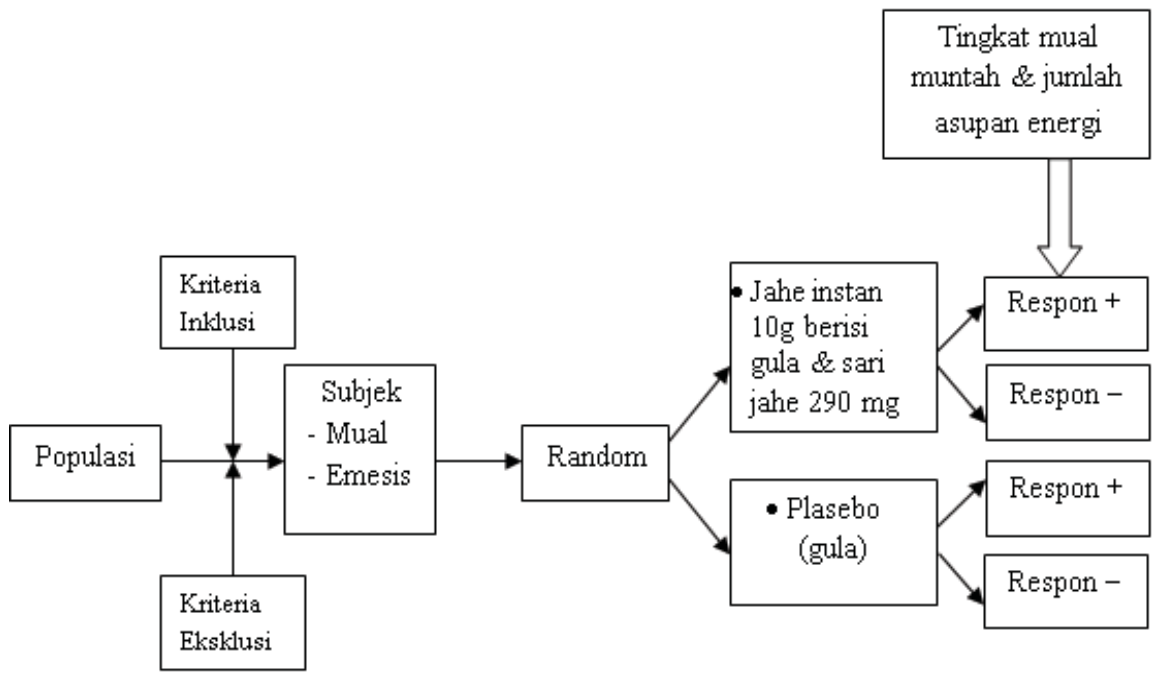

Gambar 1. Skema desain penelitian

terhadap sampel maupun plasebo yang diberikan oleh peneliti karena bentuk sampel dan plasebo serupa. Plasebo yang digunakan pada penelitian adalah gula pasir berwarna kuning kecoklatan yang diblender sehingga bentuk dan warnanya hampir sama dengan serbuk jahe instan.

Selanjutnya, subjek penelitian dinilai tingkat mual dan muntahnya dengan instrumen indeks pregnancy-unique quantification of emesis and nausea (PUQE) modification (17) dan dilakukan food recall 24 hours untuk melihat asupan energi subjek. Penilaian tingkat mual muntah dengan instrument PUQE dibagi menjadi tiga kategori yaitu ringan $(\leq 6)$, sedang (7-12), dan berat $(\geq 13)$. Analisis univariat dan bivariat menggunakan uji Chi-Square dan t-tes, dilanjutkan dengan uji Odds Ratio (OR) dan signifikansi (McNemar). Analisis multivariat menggunakan uji regresi logistik berganda untuk mengetahui variabel luar yang mempengaruhi variabel dependen selain variabel independen. Penelitian ini telah memperoleh ethical clearance dari Komisi Etik Fakultas Kedokteran Universitas Gadjah Mada dengan nomor KE/FK/193/EC.

\section{HASIL}

\section{Karakteristik subjek}

Secara keseluruhan, subjek dalam penelitian ini berjumlah 101 orang terdiri dari 50 orang sebagai kelompok perlakuan dengan pemberian jahe instan dan 51 orang sebagai kelompok plasebo. Karakteristik umum
Tabel 1. Karakteristik dasar subjek penelitian kelompok jahe instan dan plasebo

\begin{tabular}{|c|c|c|c|c|c|}
\hline \multirow[t]{2}{*}{ Variabel } & \multicolumn{2}{|c|}{$\begin{array}{c}\text { Jahe instan } \\
(\mathrm{n}=50)\end{array}$} & \multicolumn{2}{|c|}{$\begin{array}{c}\text { Plasebo } \\
(n=51)\end{array}$} & \multirow[t]{2}{*}{$\mathbf{p}$} \\
\hline & $\mathbf{n}$ & $\%$ & $\mathbf{n}$ & $\%$ & \\
\hline \multicolumn{6}{|l|}{ Usia (tahun) } \\
\hline$\leq 20$ & 4 & 8 & 7 & 13,7 & 0,45 \\
\hline $21-29$ & 33 & 66 & 35 & 68,6 & \\
\hline$\geq 30$ & 13 & 26 & 9 & 17,6 & \\
\hline \multicolumn{6}{|c|}{ Usia kehamilan (minggu) } \\
\hline $4-7$ & 14 & 28 & 14 & 27,4 & 0,95 \\
\hline $8-14$ & 36 & 72 & 37 & 72,6 & \\
\hline \multicolumn{6}{|l|}{ Paritas } \\
\hline Multipara & 17 & 34 & 18 & 35,3 & 0,89 \\
\hline Primipara & 33 & 66 & 33 & 64,7 & \\
\hline \multicolumn{6}{|l|}{ Vitamin $\mathrm{B}_{6}$} \\
\hline $\mathrm{Ya}$ & 26 & 52 & 22 & 43,1 & 0,37 \\
\hline Tidak & 24 & 48 & 29 & 56,9 & \\
\hline \multicolumn{6}{|l|}{ Asam folat } \\
\hline Ya & 10 & 20 & 9 & 17,7 & 0,76 \\
\hline Tidak & 40 & 80 & 42 & 82,3 & \\
\hline \multicolumn{6}{|c|}{ Zat besi $(\mathrm{Fe})+$ mikronutrien lain } \\
\hline Ya & 28 & 56 & 35 & 68,6 & 0,19 \\
\hline Tidak & 22 & 44 & 16 & 31,4 & \\
\hline
\end{tabular}

subjek penelitian ini meliputi usia, berat badan, tinggi badan, usia kehamilan, paritas, dan suplementasi (vitamin $\mathrm{B}_{6}$, asam folat, zat besi dan mikronutrien lain) dapat dilihat di Tabel 1. Rerata berat badan pada kelompok jahe instan sebesar 53 $\pm 10,1 \mathrm{~kg}$ sedangkan kelompok plasebo sebesar $51,4 \pm 7,8 \mathrm{~kg}$. Sementara itu, rerata tinggi badan 
pada kelompok jahe sebesar $155,4 \pm 6,4 \mathrm{~cm}$ sedangkan kelompok plasebo sebesar $154 \pm 4,9 \mathrm{~cm}$. Berdasarkan Tabel 1 dapat diketahui bahwa data demografi kedua kelompok memiliki karakteristik yang setara. Seluruh variabel memiliki nilai p lebih dari 0,05 ( $>>0,05)$, artinya tidak ada perbedaan karakteristik antara kelompok jahe instan dan plasebo.

\section{Efektivitas jahe instan untuk mengatasi mual muntah kehamilan}

Pada Tabel 2, hasil analisis uji Chi-Square untuk tingkat mual muntah pra-intervensi menunjukkan tidak ada perbedaan yang signifikan antara kedua kelompok (sedang: jahe instan $64 \%$ vs placebo $56,9 \%$; $p>0,05$ ) sedangkan pada pasca-intervensi terdapat perbedaan yang signifikan antara

Tabel 2. Distribusi tingkat mual muntah pra dan pascaintervensi kelompok jahe instan dan plasebo

\begin{tabular}{|c|c|c|c|c|c|c|c|}
\hline \multirow{3}{*}{ Intervensi } & \multicolumn{4}{|c|}{ Tingkat mual muntah } & \multirow{2}{*}{\multicolumn{2}{|c|}{ Total }} & \multirow{3}{*}{$\mathbf{p}$} \\
\hline & \multicolumn{2}{|c|}{ Ringan } & \multicolumn{2}{|c|}{ Sedang } & & & \\
\hline & $\mathbf{n}$ & $\%$ & $\mathbf{n}$ & $\%$ & $\mathbf{n}$ & $\%$ & \\
\hline \multicolumn{8}{|l|}{ Pra } \\
\hline Jahe & 18 & 36,0 & 32 & 64,0 & 50 & 100 & 0,46 \\
\hline Plasebo & 22 & 43,1 & 29 & 56,9 & 51 & 100 & \\
\hline \multicolumn{8}{|l|}{ Pasca } \\
\hline Jahe & 44 & 88,0 & 6 & 12,0 & 50 & 100 & $0,00^{*}$ \\
\hline Plasebo & 28 & 54,9 & 23 & 45,1 & 51 & 100 & \\
\hline
\end{tabular}

Keterangan: * bermakna $(\mathrm{p}<0,05)$ kedua kelompok (ringan: jahe instan $88 \%$ vs plasebo $54,9 \%$; $\mathrm{p}<0,05)$. Hasil uji Odds Ratio menunjukkan bahwa jahe instan dapat menurunkan tingkat mual muntah 6 kali lebih besar dibandingkan plasebo $(\mathrm{OR}=6 ; \mathrm{p}<0,05)$.

\section{Efektifitas jahe instan untuk meningkatkan jumlah} asupan energi

Berdasarkan Tabel 3, hasil t-test pada rerata asupan energi pra-intervensi (jahe instan 1070,76 kcal vs plasebo 1074,99 kcal; p>0,05) menunjukkan bahwa tidak ada perbedaan rerata jumlah asupan energi praintervensi antara kelompok jahe instan dan plasebo. Hasil analisis uji paired t-test pada rerata jumlah asupan energi terlihat bahwa ada perubahan peningkatan jumlah asupan energi pada kelompok jahe instan sebesar 558,82 kcal sedangkan pada kelompok plasebo sebesar 85,28 kcal. Dapat disimpulkan bahwa terdapat perubahan yang signifikan pada rerata jumlah asupan energi pra-intervensi dibandingkan pasca pada kelompok jahe instan $(\mathrm{p}<0,05)$. Sementara itu, tidak ada perubahan yang signifikan pada rerata jumlah asupan energi pra-intervensi dibandingkan pasca pada kelompok plasebo $(\mathrm{p}>0,05)$.

Bila rerata jumlah asupan energi pasca-intervensi dikategorikan menjadi meningkat dan menurun, hasil uji Odds Ratio antara kelompok jahe instan dengan plasebo terhadap peningkatan rerata jumlah asupan energi akan didapatkan $\mathrm{OR}=24,5(\mathrm{p}<0,05)$. Artinya, jahe instan dapat

Tabel 3. Perbandingan rerata jumlah asupan energi 24 jam (kalori) pra dan pasca-intervensi ibu hamil trimester pertama antara kelompok jahe instan dan plasebo

\begin{tabular}{|c|c|c|c|c|c|c|c|c|}
\hline \multirow{3}{*}{ Intervensi } & \multicolumn{4}{|c|}{ Asupan 24 jam (kcal) } & \multirow{3}{*}{$\mathbf{t}$} & \multirow{3}{*}{$\mathbf{p}$} & \multirow{3}{*}{$\begin{array}{c}\Delta \\
\text { (kcal) }\end{array}$} & \multirow{3}{*}{$\begin{array}{c}\text { 95\% CI } \\
\text { (kcal) }\end{array}$} \\
\hline & \multicolumn{2}{|c|}{ Pra } & \multicolumn{2}{|c|}{ Pasca } & & & & \\
\hline & Rerata & SD & Rerata & SD & & & & \\
\hline Jahe & 1070,76 & 420,42 & 1629,58 & 468,04 & 6,28 & $0,00^{*}$ & 558,82 & $382,25-735,38$ \\
\hline Plasebo & 1074,99 & 359,28 & 1160,27 & 341,85 & 0,22 & 0,22 & 85,28 & $-52,49-223,05$ \\
\hline
\end{tabular}

Keterangan: $\Delta=$ selisih rerata; * bermakna $(\mathrm{p}<0,05)$

Tabel 4. Efektivitas jahe instan dibanding plasebo untuk meningkatkan rerata jumlah asupan energi

\begin{tabular}{|c|c|c|c|c|c|}
\hline \multirow{3}{*}{ Intervensi } & \multicolumn{2}{|c|}{ Rerata jumlah asupan energi } & \multirow{3}{*}{$\begin{array}{l}\text { Total } \\
(\%)\end{array}$} & \multirow{3}{*}{$\begin{array}{c}\text { OR } \\
(95 \% \mathrm{CI})\end{array}$} & \multirow{3}{*}{$\mathbf{p}$} \\
\hline & Meningkat & Menurun & & & \\
\hline & n (\%) & n (\%) & & & \\
\hline Jahe & $49(98,0)$ & $1(12,0)$ & $50(100)$ & 24,5 & \multirow{2}{*}{$0,000^{*}$} \\
\hline Plasebo & $34(66,7)$ & $17(33,3)$ & $51(100)$ & $(3,42-1044,05)$ & \\
\hline
\end{tabular}

Keterangan : * bermakna $(\mathrm{p}<0,05)$ 
Tabel 5. Pengaruh usia kehamilan, paritas, vitamin $B_{6}$, asam folat, zat besi dan mikronutrien lain dengan rerata jumlah asupan energi pasca-intervensi

\begin{tabular}{|c|c|c|c|c|c|c|c|c|}
\hline \multirow{3}{*}{ Variabel luar } & & \multicolumn{4}{|c|}{$\begin{array}{c}\text { Rerata jumlah asupan energi } \\
\text { (pasca-intervensi) }\end{array}$} & \multirow{3}{*}{ OR } & \multirow{3}{*}{$\mathbf{p}$} & \multirow{3}{*}{$95 \% \mathrm{CI}$} \\
\hline & & \multicolumn{2}{|c|}{ Meningkat } & \multicolumn{2}{|c|}{ Menurun } & & & \\
\hline & & $\mathbf{n}$ & $\%$ & $\mathbf{n}$ & $\%$ & & & \\
\hline \multirow{2}{*}{$\begin{array}{l}\text { Usia kehamilan } \\
\text { (minggu) }\end{array}$} & $4-7$ & 24 & 85,7 & 4 & 14,3 & 1,42 & 0,56 & $0,39-6,52$ \\
\hline & $8-14$ & 59 & 80,8 & 14 & 19,2 & & & \\
\hline \multirow[t]{2}{*}{ Paritas } & Multipara & 31 & 88,6 & 4 & 11,4 & 2,08 & 0,22 & $0,58-9,42$ \\
\hline & Primipara & 52 & 78,8 & 14 & 21,2 & & & \\
\hline \multirow[t]{2}{*}{ Vitamin $\mathrm{B}_{6}$} & $\mathrm{Ya}$ & 44 & 91,7 & 4 & 8,3 & 3,9 & $0,018^{*}$ & $1,10-17,64$ \\
\hline & Tidak & 39 & 73,6 & 14 & 26,4 & & & \\
\hline \multirow[t]{2}{*}{ Asam folat } & Ya & 17 & 89,5 & 2 & 10,5 & 2,0 & 0,35 & $0,41-20,08$ \\
\hline & Tidak & 66 & 80,5 & 16 & 19,5 & & & \\
\hline \multirow[t]{2}{*}{ Zat besi dan mikronutrien lain } & $\mathrm{Ya}$ & 25 & 69,4 & 11 & 30,6 & 0,27 & $0,013^{*}$ & $0,08-0,89$ \\
\hline & Tidak & 58 & 89,2 & 7 & 10,8 & & & \\
\hline
\end{tabular}

Keterangan: *: bermakna $(\mathrm{p}<0,05)$

Tabel 6. Analisis multivariat paritas, vitamin $B_{6}$, dan zat besi + mikronutrien terhadap rerata jumlah asupan energi pasca-intervensi

\begin{tabular}{|c|c|c|c|c|c|}
\hline \multirow{3}{*}{ Variabel } & \multicolumn{5}{|c|}{ Rerata jumlah asupan energi (pasca-intervensi) } \\
\hline & Model 1 & Model 2 & Model 3 & Model 4 & Model 5 \\
\hline & OR $(95 \% \mathrm{CI})$ & OR $(95 \% \mathrm{CI})$ & OR $(95 \%$ CI $)$ & OR $(95 \% \mathrm{CI})$ & OR $(95 \% \mathrm{CI})$ \\
\hline \multicolumn{6}{|l|}{ Independen } \\
\hline Jahe & $24,5^{*}$ & $25,92^{*}$ & $24,79^{*}$ & $23,89^{*}$ & $26,90^{*}$ \\
\hline Plasebo & $(3,11-192,9)$ & $(3,26-206,03)$ & $(3,09-198,78)$ & $(2,98-191,51)$ & $(3,26-221,39)$ \\
\hline \multicolumn{6}{|l|}{ Paritas } \\
\hline Multipara & & 2,46 & & & 2,84 \\
\hline Primipara & & $(0,68-8,90)$ & & & $(0,72-11,24)$ \\
\hline \multicolumn{6}{|l|}{ Vitamin $\mathrm{B}_{6}$} \\
\hline Ya & & & 4,03 & & 2,52 \\
\hline Tidak & & & $(1,12-14,47)$ & & $(0,50-12,66)$ \\
\hline \multicolumn{6}{|c|}{ Zat besi + mikronutrien lain } \\
\hline Ya & & & & 0,28 & 0,44 \\
\hline Tidak & & & & $(0,08-0,91)$ & $(0,09-1,99)$ \\
\hline $\mathrm{R}^{2}(\%)$ & $21 \%$ & $23 \%$ & $26 \%$ & $25 \%$ & $29 \%$ \\
\hline $\mathrm{N}$ & 101 & 101 & 101 & 101 & 101 \\
\hline Deviance & 74,72 & 72,68 & 69,56 & 70,12 & 66,32 \\
\hline
\end{tabular}

Keterangan: * bermakna $(\mathrm{p}<0,05)$

meningkatkan rerata jumlah asupan energi 24,5 kali lebih besar dibandingkan plasebo (Tabel 4).

Pada Tabel 5, hasil uji antara usia kehamilan dan asam folat dengan rerata jumlah asupan energi didapatkan nilai $\mathrm{p}$ lebih dari 0,05 sehingga dapat dikatakan antara usia kehamilan dan penggunaan asam folat tidak mempengaruhi rerata jumlah asupan energi pasca-intervensi. Sementara pada variabel paritas, suplementasi vitamin $\mathrm{B}_{6}$ dan zat besi+mikronutrien lain memiliki p kurang dari 0,25 sehingga dilakukan analisis multivariat dengan uji regresi logistik berganda. Hasil analisis multivariat (Tabel 6) menunjukkan bahwa nilai Odds Ratio variabel independen lebih dari 1 dalam setiap model dan variabel luar juga mempunyai OR lebih dari 1 . Berdasarkan penghitungan stratifikasi pada setiap model didapatkan bahwa semua variabel luar bukan merupakan faktor pengganggu (selisih OR $<20 \%$ ). Variabel luar berinteraksi terhadap variabel independen. 


\section{BAHASAN}

Studi klinis menunjukkan bahwa jahe memiliki efek langsung pada saluran pencernaan dengan meningkatkan motilitas lambung serta absorpsi racun dan asam (5). Jahe diperkirakan meningkatkan tonus otot usus dan merangsang aliran air liur, empedu, dan sekresi lambung. Salah satu kandungan senyawa jahe adalah diterpenoid yang telah terbukti memiliki aktivitas yang mirip dengan neurotrasmitter 5-HT3 antagonis seperti ondansetron dan obat emetik lainnya (18). Hasil penelitian ini tidak jauh berbeda dengan hasil dari penelitian-penelitian yang telah dilakukan sebelumnya (6-12), semua penelitian tersebut memberikan hasil bahwa ekstrak jahe dalam kapsul secara signifikan menurunkan frekuensi dan episode mual muntah kehamilan. Dosis jahe yang terkandung dalam jahe instan adalah $290 \mathrm{mg}$ sari jahe (setara dengan $100 \mathrm{~g}$ jahe basah) dalam setiap kemasan. Berdasarkan penelitianpenelitian sebelumnya, pemberian ekstrak jahe sampai dengan dosis $1000 \mathrm{mg}(1 \mathrm{~g})$ atau $2 \mathrm{~g}$ bubuk jahe kering per hari masih dalam batas aman (6-11).

Keluhan mual muntah menjadi salah satu penyebab kurangnya asupan energi dan gizi pada ibu hamil. Meskipun tubuh memiliki kemampuan luar biasa untuk mengompensasi kekurangan dan kelebihan gizi, wanita yang sedang hamil tidak dapat menyediakan gizi penting bagi anaknya jika ia sendiri kekurangan gizi dalam diri mereka. Seluruh asupan energi dan gizi wanita ketika hamil dapat berpengaruh besar dan memiliki efek yang bertahan lama pada kesehatan anak-anaknya (19).

Mengurangi intensitas dan durasi mual muntah dengan mengonsumsi jahe telah banyak dianjurkan oleh ahli medis. Hasil review memuat tata laksana manajemen mual muntah kehamilan dengan menganjurkan penggunaan jahe sebagai terapi alternatif non-farmakologi $(19,20)$. Dengan berkurangnya intensitas dan durasi mual muntah pada ibu hamil, dapat memperbaiki asupan energi yang kurang baik di awal kehamilan. Pada penelitian ini terlihat bahwa pemberian jahe instan dapat membantu meningkatkan rerata jumlah asupan energi 24 jam (kalori) ibu hamil trimester pertama yang mengalami mual muntah kehamilan. Senyawa aktif jahe yang terkandung dalam jahe instan mampu menurunkan tingkat mual muntah kehamilan trimester pertama. Jahe instan mampu memberikan rasa nyaman pada ibu terutama pada keluhan mual dan muntah kehamilan. Beberapa hal yang perlu dijadikan pertimbangan dalam melihat asupan energi dan gizi ibu hamil adalah faktor-faktor yang dapat mempengaruhi asupan ibu hamil, yaitu: 1) kebiasaan dan pandangan wanita terhadap makanan; 2) status ekonomi; 3) pengetahuan zat gizi dalam makanan; 4) status kesehatan; 5) pola aktivitas; 6) suhu lingkungan; 7) berat badan; dan 8) usia (21). Penelitian lebih lanjut diperlukan untuk melihat sejauh mana pengaruh usia kehamilan, paritas, dan penggunaan suplementasi terhadap kejadian mual muntah dan peningkatan asupan energi pada ibu hamil yang minum jahe instan.

\section{SIMPULAN DAN SARAN}

Pemberian jahe instan dengan dosis $290 \mathrm{mg}$ (sari jahe) berpengaruh menurunkan kejadian mual muntah pada ibu hamil trimester pertama. Jahe instan dapat menurunkan tingkat mual muntah 6 kali lebih besar dibandingkan plasebo. Ada peningkatan jumlah asupan energi pada ibu hamil dengan mual muntah kehamilan yang diberi jahe instan dengan dosis $290 \mathrm{mg}$ dibandingkan plasebo. Jahe instan dapat meningkatkan rerata jumlah asupan energi 24,5 kali lebih besar dibandingkan plasebo.

Berdasarkan hasil dari penelitian ini, disarankan kepada ibu hamil untuk meminum jahe instan sebagai penanganan pertama yang relatif aman dibandingkan meminum obat tanpa resep dokter. Tenaga kesehatan bisa menggunakan jahe instan sebagai salah satu penanganan alternatif dan komplementer melengkapi pengobatan standar untuk mengatasi emesis gravidarum. Dinas Kesehatan Kota Balikpapan diharapkan agar mengembangkan produksi jahe instan yang terstandar Depkes. Perlu dilakukan penelitian dengan waktu yang lebih panjang untuk membuktikan konsistensi manfaat nutrasetikal (jahe) terhadap penanganan mual muntah pada kehamilan dan upaya peningkatan asupan energi ibu hamil trimester pertama yang terganggu akibat mual muntah kehamilan. 


\section{RUJUKAN}

1. Waryono. Gizi reproduksi. Yogyakarta: Pustaka Rihama; 2010.

2. Chomaria N. Five in one, the series of pregnancy: makanan sehat seimbang untuk ibu hamil. Jakarta: Elex Media Komputindo. 2012.

3. Sherman PW, Flaxman SM. Nausea and vomiting of pregnancy in an evolutionary perspective. Am J Obstet Gynecol [series online] 2002 [cited 2012 Mei 28];186(5):S190-7. Available from: URL: http://www2.uah.es/salud-yenfermedad/pdf/ Nausea $\% 20$ and $\% 20$ vomiting $\% 20$ of $\% 20$ pregnancy $\% 20$ in $\% 20$ an $\% 20$ evolutionary $\% 2$ perspective.pdf

4. Chrubasik S, Pittler MH, Roufogalis BD. Review: zingiberis rhizoma: a comprehensive review on the ginger effect and efficacy profiles. Phytomedicine [series online] 2005 [cited 2012 Mei 28];12(9):684-701. Available from: URL: http:// nutraxin.com.tr/pdf/ZingiberOfficinale/Zingiber_03.pdf

5. World Health Organization. WHO monographs on select medicinal plants. [series online] 1999 [cited 2012 Mei 28]. Available from: URL: http://whqlibdoc.who.int/ publications/1999/9241545178.pdf

6. Vutyavanich T, Kraisarin T, Ruangsri RA. Ginger for nausea and vomiting in pregnancy: randomized, double-masked, placebo-controlled trial. Obstet Gynecol [series online] 2001 [cited 2012 Mei 28];97(4):577-82. Available from: URL: http://journals.lww.com/greenjournal/Fulltext/2001/04000/ Ginger_for_Nausea_and_Vomiting_in_Pregnancy_17.aspx

7. Willetts KE, Ekangaki A, Eden JA. Effect of a ginger extract on pregnancy-induced nausea: A randomised controlled trial. Aust N Z J Obstet Gynaecol 2003;43(2):139-44.

8. Smith C, Crowther C, Willson K, Hotham N, McMillian $\mathrm{V}$. A randomized controlled trial of ginger to treat nausea and vomiting in pregnancy. Obstet Gynecol [series online] 2004 [cited 2012 Mei 28];103(4):639-45. Available from: URL: http://journals.1ww.com/greenjournal/ Fulltext/2004/04000/A_Randomized_Controlled_Trial_of_ Ginger_to_Treat.6.aspx. 2004 Apr;103(4):639-45.

9. Chittumma P, Kaewkiattikun K, Wiriyasiriwach B. Comparison of the effectiveness of ginger and vitamin b6 for treatment of nausea and vomiting in early pregnancy: a randomized double-blind controlled trial. J Med Assoc Thai [series online] 2007 [cited 2012 Mei 28];90(1):15-20. Available from: URL: http://www.mat.or.th/journal/files/ Vol90_No.1_15_7334.pdf

10. Pongrojpaw D, Somprasit C, Chanthasenanont A. A randomized comparison of ginger and dimenhydrinate in the treatment of nausea and vomiting in pregnancy. J Med Assoc Thai [series online] 2007 [cited 2012 Mei 28];90(9):1703-9. Available from: URL: http://www.mat.or.th/journal/files/ Vol90_No.9_1703_5990.pdf
11. Ozgoli G, Goli M, Simbar M. Effects of ginger capsules on pregnancy, nausea, and vomiting. J Altern Complement Med [series online] 2009 [cited 2012 Mei 28];15(3):243-6. Available from: URL: http://69.164.208.4/files/Effects\%20 of $\% 20$ Ginger $\% 20$ Capsules $\% 20$ on $\% 20$ Pregnancy, $\% 20$ Nausea,\%20and\%20Vomiting.pdf

12. Arianto K. Keefektifan pemberian ekstrak jahe dan kombinasi ekstrak jahe dengan piridoksin untuk mual dan muntah pada emesis gravidarum [Tesis]. Yogjakarta: Universitas Gadjah Mada; 2008.

13. Bryer, E. A literature review of the effectiveness of ginger in alleviating mild-to-moderate nausea and vomiting of pregnancy. J Midwifery Womens Health [series online] 2005 [cited 2012 Mei 28];50(1):e1-3. Available from: URL: http:// www.ncbi.nlm.nih.gov/pubmed/15637501

14. Matthews A, Dowswell T, Haas DM, Doyle M, O’Mathúna DP. Interventions for nausea and vomiting in early pregnancy. Cochrane Database Syst Rev 2010;9:CD007575. doi: 10.1002/14651858.CD007575.pub2.

15. Dinas Kesehatan Kota Balikpapan. Profil kesehatan 201. [series online] 2011 [cited 2012 Nov 10]. Available from: URL: http://dkk.balikpapan.go.id/index.php?option=com_c ontent\&task=view \&id=137\&Itemid=103

16. Lemeshow S, Hosmer DW, Klar J, Lwanga S. Besar sampel dalam penelitian kesehatan. Alih bahasa: Pramono D. Yogjakarta: Gadjah Mada University Press; 1997.

17. King TL, Murphy PA. Evidence-based approaches to managing nausea and vomiting in early pregnancy. J Midwifery Womens Health [series online] 2009 [cited 2012 Mei 28]; 54(6):430-44. Available from: URL: http://www. medscape.com/viewarticle/712662

18. Davis M. Nausea and vomiting of pregnancy an evidencebased review. J Perinat Neonatal Nurs [series online] 2004 [cited 2012 Mei 28];18(4):312-28. Available from: URL: http://www.utilis.net/Morning\%20Topics/Obstetrics/ Hyperemesis.pdf

19. American College of Obstetricians and Gynecologists (ACOG) Comitte. Nausea and vomiting of pregnancy. ACOG practice guideline: clinical management guidelines for obstetrician and gynecologist No. 52 [series online] 2004 [cited 2012 Mei 28]. Available from: URL: http://www. molinahealthcare.com/medicaid/providers/mo/pdf/acog\%20 nausea $\% 20 \% 20$ vomiting\%20pregnancy.pdf?E=true

20. Einarson A, Maltepe C, Boskovic R, Koren G. Treatment of nausea and vomiting in pregnancy: an updated algorithm. Can Fam Physician [series online] 2007 [cited 2012 Mei 28];53(12):2109-11. Available from: URL: http://www.cfp. $\mathrm{ca} /$ content/53/12/2109.full.pdf + html

21. Kristiyanasari W. Gizi ibu hamil. Yogyakarta: Nuha Medik; 2010. 